\title{
Limulus amoebocyte lysate assay in the diagnosis of peritonitis in patients receiving continuous ambulatory peritoneal dialysis
}

\author{
R A Bowman, A S Medley, K T Karthigasu
}

\begin{abstract}
Aims: To evaluate the Limulus amoebocyte lysate (LAL) assay for differentiating Gram positive from Gram negative peritonitis in patients receiving continuous ambulatory peritoneal dialysis (CAPD).
\end{abstract}

Methods: One hundred and six patients with suspected peritonitis were studied. LAL assay was performed by adding 0.1 $\mathrm{ml}$ of CAPD fluid to $0.1 \mathrm{ml}$ of $L A L$ reagent and incubatng in a heating block for 60 minutes at $37^{\circ} \mathrm{C}$. The sensitivity of the reaction was determined by: (i) diluting endotoxin in distilled water and used (filter sterilised) peritoneal dialysis fluid; and (ii) diluting a broth culture of $E$ coli used in peritoneal dialysis fluid. A positive LAL assay was defined as the constant stability of the clot through an inversion of $180^{\circ}$.

Results: Compared with bacterial culture, the LAL assay had a sensitivity of $65 \%$ and a specificity of $98 \%$. The sensitivity of microscopy compared with culture of Gram negative organisms was $76 \%$; overall sensitivity of microscopy in comparison was $80 \%$.

Conclusions: The Gram stain was more sensitive than has previously been reported; the LAL assay was specific but insensitive for the diagnosis of CAPD peritonitis. There was a correlation between reduced leucocyte count and culture; this was reduced in cases from which Gram negative organisms had been isolated. It is recommended that laboratories evaluate their Gram stain procedure to improve its sensitivity because the LAL assay is not a satisfactory substitute.

Department of
Microbiology,
University of Western
Australia, State
Health Laboratory
Services and Sir
Charles Gairdner
Hospital, Queen
Elizabeth II Medical
Centre, Nedlands 6009,
Western Australia
R A Bowman
A S Medley
K T Karthigasu
Correspondence to:
Mr R B Bowman
Accepted for publication
4 July 1991

Continuous ambulatory peritoneal dialysis (CAPD) is becoming more widely used as an alternative to haemodialysis in patients with end-stage renal disease, but bacterial peritonitis remains a major complication. ${ }^{1}$ Although isolation and identification of the causative organism remains the priority of the clinical bacteriology laboratory in the diagnosis of peritonitis in patients receiving CAPD, one aspect that has received attention recently is the use of the Limulus amoebocyte lysate (LAL) assay. ${ }^{2}$ The LAL assay has been reported to differentiate reliably peritonitis due to either
Gram negative or Gram positive organisms. ${ }^{34}$ The emphasis has been directed towards rapid diagnosis to exclude the presence of Gram negative bacteria to facilitate more specific treatment, possibly avoiding the exposure of patients to potentially ototoxic aminoglycosides. This approach has been suggested due to the lack of sensitivity of the Gram stain for the rapid diagnosis of CAPD peritonitis. This report describes an evaluation of the LAL (gel clot) assay in differentiating peritonitis due to either Gram negative or Gram positive organisms. We compared the sensitivity of the LAL assay and direct microscopy with culture for the rapid diagnosis of Gram negative peritonitis. We also assessed the theoretical sensitivity of the LAL assay for detecting Gram negative bacilli in used, sterile peritoneal dialysis fluid.

\section{Methods}

Peritoneal dialysis fluids from patients with suspected peritonitis who attended the renal unit at Sir Charles Gairdner Hospital, a 700bed general hospital, were examined in the study. Fluids were stored at $4^{\circ} \mathrm{C}$ until routine bacteriological investigation; the delay in processing specimens was never more than two hours. If the LAL assay was not performed immediately the specimen was frozen at $-20^{\circ} \mathrm{C}$ until assayed.

On receipt of the specimen in the laboratory, $50 \mathrm{ml}$ was removed asceptically with a sterile syringe. A $20 \mathrm{ml}$ aliquot was centrifuged at $3000 \mathrm{rpm}$ for 10 minutes in a bench centrifuge and the deposit resuspended in $1.0 \mathrm{ml}$. One drop $(0.1 \mathrm{ml})$ was used to inoculate a horse haematin agar (HH) plate, a cysteine lactose electrolyte deficient (CLED) agar plate, two blood agar plates, and a blood agar plate containing saponin (SBA). The SBA, one blood agar, and $\mathrm{HH}$ agar plates were incubated at $35^{\circ} \mathrm{C}$ for 48 hours in an atmosphere containing 5\% carbon dioxide; the CLED plate was incubated aerobically at $35^{\circ} \mathrm{C}$ for 24 hours, and the remaining blood agar plate was incubated in an anaerobic chamber (Don Whitley Scientific Ltd) at $35^{\circ} \mathrm{C}$ for $\mathbf{4 8}$ hours. A Gram stained smear was also prepared from the centrifuged deposit. A $5 \mathrm{ml}$ sample of the neat fluid was also inoculated into aerobic and anaerobic blood culture bottles (Bactec 6A and 7A) which were incubated at $35^{\circ} \mathrm{C}$ for five days.

The LAL assay was performed by adding $0 \cdot 1$ 
$\mathrm{ml}$ of CAPD fluid to $0.1 \mathrm{ml}$ of LAL reagent (Pyrogent, Whittakers Bioproducts; Walkersville, Maryland, USA) and incubating it in a heating block at $37^{\circ} \mathrm{C}$ for 60 minutes. The reaction was carried out in $10 \times 75 \mathrm{~mm}$ glass tubes that had been depyrogenated by heating in a hot air oven at $180^{\circ} \mathrm{C}$ for four hours. A positive control containing $0.12 \mathrm{EU} / \mathrm{ml}$ (Escherichia coli O55:B5 endotoxin, Whittakers Bioproducts) and a negative control (pyrogen free water) were used with each LAL assay. A positive LAL result was defined as a tube showing clot formation that remained intact after inversion of the tube through 180 degrees.

The relative sensitivity of the LAL reaction in used peritoneal dialysis fluid was determined by two methods. The first involved dilution of endotoxin in distilled water and used (filter sterilised) peritoneal dialysis fluid followed by the standard LAL assay. The second was by dilution of a broth culture of $E$ coli (NCTC 10418) in used peritoneal dialysis fluid. Each dilution was then assayed by $L A L$, and viable counts were performed by dilution in physiological saline and plating $0.1 \mathrm{ml}$ volumes on to CLED agar plates.

\section{Results}

One hundred and six CAPD fluids were examined during the study. Of these, 69 were culture positive-17 with Gram negative bacteria and 54 with Gram positive bacteria (two specimens yielded both Gram negative and Gram positive organisms). Of the 17 fluids that yielded a Gram negative organism, 11 were positive in the LAL assay, while of the 91 fluids that did not yield a Gram negative organism on culture, two were positive in the LAL assay. In

Table 1 Comparison of LAL assay with culture for diagnosis of $C A P D$ peritonitis

\begin{tabular}{llc}
\hline & \multicolumn{2}{l}{ Culture (Gram negative bacteria) } \\
\cline { 2 - 3 } LAL & Positive & Negative \\
\hline Positive & 11 & $2^{\star}$ \\
Negative & 6 & 89 \\
Totals & 17 & 91 \\
\hline
\end{tabular}

*Gram negative organisms seen at microscopy in one case.

Table 2 Association between culture, microscopy, and LAL assay in laboratory diagnosis of CAPD peritonitis

\begin{tabular}{|c|c|c|c|c|c|}
\hline \multirow[b]{2}{*}{ Organism } & \multirow[b]{2}{*}{ Number } & \multicolumn{2}{|c|}{ Microscopy } & \multicolumn{2}{|l|}{$L A L$} \\
\hline & & Positive & Negative & Positive & Negative \\
\hline $\begin{array}{l}\text { E coli } \\
\text { Psewdomonas spp } \\
\text { Serratia spp } \\
\text { E cloacae } \\
\text { Klebsiella spp } \\
\text { Compylobacter jejweni } \\
\text { Bacteroides cattarhalis }\end{array}$ & $\begin{array}{l}4 \\
4 \\
2 \\
2 \\
3 \\
1 \\
1\end{array}$ & $\begin{array}{l}4 \\
4 \\
1 \\
1 \\
3 \\
0 \\
0\end{array}$ & $\begin{array}{l}0 \\
0 \\
1 \\
1 \\
0 \\
1 \\
1\end{array}$ & $\begin{array}{l}\mathbf{4} \\
3 \\
1 \\
1 \\
2 \\
0 \\
\mathbf{0}\end{array}$ & $\begin{array}{l}0 \\
1 \\
1 \\
1 \\
1 \\
1 \\
1\end{array}$ \\
\hline Totals & 17 & 13 & 4 & 11 & 6 \\
\hline $\begin{array}{l}\text { Sepidermidis } \\
\text { viridans Streptococci } \\
\text { S aureus } \\
\text { Corymebacterivan spp } \\
\text { Candida albicans } \\
\text { S hominis } \\
\text { S warmeri } \\
\text { Enterococcus faecalis }\end{array}$ & $\begin{array}{r}31 \\
6 \\
5 \\
4 \\
4 \\
2 \\
1 \\
1\end{array}$ & $\begin{array}{r}25 \\
6 \\
5 \\
2 \\
4 \\
1 \\
1 \\
0\end{array}$ & $\begin{array}{l}\mathbf{6} \\
\mathbf{0} \\
\mathbf{0} \\
\mathbf{2} \\
\mathbf{0} \\
\mathbf{1} \\
\mathbf{0} \\
\mathbf{1}\end{array}$ & $\begin{array}{l}\mathbf{0} \\
\mathbf{0} \\
\mathbf{1} \\
\mathbf{0} \\
\mathbf{0} \\
\mathbf{0} \\
\mathbf{0} \\
\mathbf{0}\end{array}$ & $\begin{array}{r}31 \\
6 \\
4 \\
4 \\
4 \\
2 \\
1 \\
1\end{array}$ \\
\hline Totals & 54 & 44 & 10 & 1 & 53 \\
\hline
\end{tabular}

Table 3 Sensitivity of LAL assay in water and peritoneal fluid

\begin{tabular}{lll}
\hline \multirow{2}{*}{$\begin{array}{lll}\text { Endotoxin concentration } \\
\text { EU/ml }(p g / m l)\end{array}$} & Diluent \\
\cline { 2 - 3 } & Water & Used peritoneal fluid \\
\hline $1 \cdot 0(100)$ & + & + \\
$0.5(50)$ & + & + \\
$0 \cdot 25(25)$ & + & - \\
$0 \cdot 12(12)$ & + & - \\
$0.06(6)$ & - & - \\
Negative control & &
\end{tabular}

one of these fluids, however, Gram negative bacilli were seen at microscopy but failed to grow on culture. The remaining LAL positive (culture negative for Gram negative bacteria) fluid yielded Staphylococcus aureus only and did not show the presence of Gram negative bacteria at microscopy. All 37 culture negative cases were negative in the LAL assay. These results are summarised in table 1 . Therefore the sensitivity and specificity of the LAL assay with respect to culture were $65 \%$ and $98 \%$, respectively.

Of 17 Gram negative isolations, 13 were detected at microscopy. Therefore the sensitivity of microscopy compared with culture was $76 \%$. Of $54 \mathrm{Gram}$ positive isolations, 44 were detected at microscopy. Overall, 57 of the 71 isolates were detected at microscopy (sensitivity $\mathbf{8 0} \%$ ). These results, together with the respective LAL assays, are shown in table 2.

To determine the sensitivity of the LAL assay in peritoneal dialysis fluid compared with water, serial dilutions of an endotoxin standard were prepared in sterilised, distilled water and used, filter sterilised peritoneal dialysis fluid. The LAL assay achieved the stated sensitivity of the lysate batch $(0.12 \mathrm{EU} / \mathrm{ml})$ in water, but there was a fourfold decrease in sensitivity to $0.5 \mathrm{EU} / \mathrm{ml}$ using peritoneal dialysis fluid (table 3). Tenfold dilutions of a broth culture of $E$ coli NCTC 10418 were prepared in distilled water and used, filter sterilised peritoneal dialysis fluid, and each dilution was then subjected to LAL assay and a count for viability. The LAL assay detected $1000 \mathrm{CFU} E$ coli $/ \mathrm{ml}$ in both distilled water and used peritoneal dialysis fluid.

\section{Discussion}

The primary aim of this study was to evaluate the application of the LAL assay in differentiating Gram positive from Gram negative peritonitis. During the study, however, other important aspects of the laboratory diagnosis of peritonitis in patients with CAPD became apparent and warrant comment.

The Gram stain was more sensitive than has been previously reported. Knight et al $l^{5}$ reported the sensitivity of Gram stain to be $16 \%$ overall, and $19 \%$ when compared with culture. Other workers have reported sensitivities ranging from $9 \%$ to $50 \%{ }^{6}$ In our study 57 of 71 $(80 \%)$ culture positive episodes of peritonitis were detected by Gram stain.

Another interesting feature that emerged was the relation between culture and leucocyte count. The mean leucocyte count in cases of 
peritonitis with Gram positive organisms was 4200/ $\mu$ l compared with $380 / \mu l$ from cases with Gram negative organisms (results not shown). In one case of peritonitis from which Enterobacter cloacae was isolated the cell count was only 10 white cells/ $\mu \mathrm{l}$. This reduced leucocyte response may be related to the reportedly increased morbidity associated with Gram negative CAPD peritonitis. ${ }^{7}$

Our study showed that the LAL assay was specific but insensitive for the diagnosis of CAPD peritonitis. This contrasts with the results of other investigators. Smalley et $a l^{4}$ used a chromogenic assay and reported a sensitivity of $100 \%$, but five of 63 culture negative fluids were LAL positive (specificity $92 \%$ ), and nine of 49 fluids which contained Gram positive organisms only were also LAL positive (specificity $82 \%$ ). Using a gel-clot assay, Clayman et $\mathrm{al}^{2}$ reported a sensitivity of $100 \%$ and a specificity of $86 \%$ and, similarly, McCartney et $\mathrm{al}^{3}$ reported a sensitivity and specificity of $100 \%$. These were small studies, however, with only three cases of Gram negative peritonitis in each.

The favourable sensitivity figure (0.01 EU/ $\mathrm{ml})$ reported by Clayman et $\mathrm{al}^{2}$ may have been due, in part, to the criterion they used to define a positive LAL assay. They defined a positive LAL assay as one that formed a partially stable clot, whereas the more widely accepted criterion for a positive $\mathrm{LAL}$ assay requires the clot to be stable through a $180^{\circ}$ inversion of the tube. Their sensitivity was roughly 10 times that which we and McCartney et al $^{3}$ achieved $(0.12 \mathrm{EU} / \mathrm{ml})$. The sensitivity achieved by Clayman et $a l^{2}$ in used peritoneal dialysis fluid $(0.20 \mathrm{EU} / \mathrm{ml})$, however, was similar to ours $(0.50 \mathrm{EU} / \mathrm{ml})$ and to that of McCartney et al $(0 \cdot 25 \mathrm{EU} / \mathrm{ml})^{3}$

We determined the sensitivity of the LAL assay to be 1000 bacteria/ml using a viable count assay, or $0.5 \mathrm{EU} / \mathrm{ml}(50 \mathrm{pg} / \mathrm{ml})$ using a diluted endotoxin standard. This is consistent with the observation that a single Gram negative bacterium contains $40 \mathrm{fg}$ of endotoxin. ${ }^{8}$ This is similar to the finding of McCartney et $a l,{ }^{3}$ who reported a theoretical detection limit of 500 bacteria $/ \mathrm{ml}$ based on their assay sensitivity of $0.25 \mathrm{EU} / \mathrm{ml}(25 \mathrm{pg} / \mathrm{ml})$ and each bacterium containing $40 \mathrm{fg}$ of endotoxin. Our findings, however, do not support the comments by McCartney et $a l^{3}$ that 100000 bacteria/ml are required before the Gram stain is able to detect them.

In our study the sensitivity of the Gram stain was $80 \%$; this is dependent on volume centrifuged, resuspension volume, time and speed of centrifugation and, to some extent, the experience and time spent by the examiner. Accordingly, we recommend that laboratories evaluate their Gram stain procedure in an effort to improve sensitivity, and suggest that the LAL assay is not a satisfactory substitute for a well performed Gram stain.

1 Fenton SSA, Pei Y, Delmore, et al. The CAPD peritonitis rate is not improving with time. Trans $\mathrm{Am}$ Soc Intern Organs 1986;32:546-9.

2 Clayman MD, Raymond R, Colen D, Moffit C, Wolf C, Neilson EG. The Limulus amoebocyte lysate assay. A rapid and sensitive method for diagnosing early Gramrapid and sensitive method for diagnosing early Gramnegative peritonitis in patients undergoing continuous
ambulatory peritoneal dialysis. Arch Intern Med 1987; ambulatory

3 McCartney AC, Brunton JN, Warwick GL. Limulus amoebocyte lysate (LAL) assay and rapid detection of Gram-negative bacterial peritonitis in patients receiving CAPD. J Clin Pathol 1989;42:1115.

4 Smalley DL, Baddour LM, Krauss AP. Rapid detection of Gram-negative bacterial peritonitis by the Limulus amoebocyte lysate assay. $J$ Clin Microbiol 1986;24:882-3.

5 Knight KR, Polak A. Laboratory diagnosis and oral treatment of CAPD peritonitis. Lancet 1982;ii:1301-4.

6 Levison ME, Bush LM. Peritonitis and other intraabdominal infections. In: Mandell GL, Douglas RG, Bennett JE, eds. Principles and practice of infectious diseases. New York: Churchill Livingstone, 1990:636-69. 7 Vas SI. Microbiology aspects of chronic ambulatory peritoneal dialysis. Kidney Int 1983;23:83-92.

8 Novitsky TJ. Pyroburden. In: Novitsky TJ, ed. LAL update. Woods Hole, Massachusetts: Associates of Cape Cod Inc, 1984:5. 